\title{
ANALYTICAL METHOD TO DETERMINE THE POTENTIAL OF USING RICE HUSK FOR OFF GRID ELECTRICITY AND HEAT GENERATION
}

\author{
A. Ame-Oko1, ${ }^{*}$, B. A. Adegboye ${ }^{2}$ and J. Tsado ${ }^{3}$ \\ 1, ElECTRICAL \& ElECTRONICS ENGINEERING DEPT. UNIVERSITY OF AGRICULTURE MAKURDI, BENUE STATE, NIGERIA

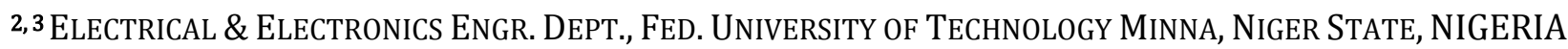 \\ E-mail addresses:1ame-oko@uam.edu.ng,2tunde.adegboye@futminna.edu.ng3j.tsado@yahoo.com
}

\begin{abstract}
This work develops an analytical method of determining the captive Combined Heat and Power (CHP) potential of the rice husk produced at the rice mills. Technologies whose commercial efficacy has been established for generating electricity and heat from rice husk were analysed using sets of thermo-chemical and thermodynamics equations to determine their CHP potential for the same amount of input rice husk. Four power plants were considered: boilersteam turbine combination labelled Plant $A$, gasifier-boiler-steam turbine combination labelled Plant $B$, gasifier-gas turbine combination labelled Plant $C$ and gasifier-Internal Combustion engine combination labelled Plant D. Results from the analysis shows that $4.85 \mathrm{~kg}, 6.82 \mathrm{~kg}, 0.87 \mathrm{~kg}$, and $0.97 \mathrm{~kg}$ are required to produce a kilowatt-hour of electricity by plants $A, B, C$ and $D$ respectively; while the heat co-generation potential of the plants $A, B, C$ and $D$ obtained are 10,051.09 MJ/hr, 7,136.24 MJ/hr, 4,182.95 MJ/hr and 6,604.67 MJ/hr respectively. Hence, a gasifier-gas turbine CHP plant is the most viable means of utilizing rice husk for off grid CHP generation while a gasifier-boilersteam turbine CHP plant is the least viable.
\end{abstract}

Keywords: rice husk ash, renewable energy, heat generation, CHP, gasifier-gas turbine CHP

\section{INTRODUCTION}

The quantity of rice husk waste produced at rice mills is substantial, $20 \%$ by weight of milled paddy [1]. It is therefore a common sight to see huge heaps of rice husk dumps around the vicinity of rice mills in areas where the husk is not used by activities such as land filling, animal bedding, fertilizer, as well as domestic heating and cooking fuel $[2,9]$. These rice husk dumps poses environmental concerns such as pollution of the atmosphere when in a bid to dispose of the waste, mill operators burn the heaps. A large and valuable expanse of land is also taken up by these rice husk dumps. To ameliorate the problems posed by these rice husk dumps, an effective means of disposal or usage of the husk ought to be adopted, hence this analysis of determining the CHP potential of rice husk.

One research puts the energy content of rice husk at $13.643 \mathrm{MJ} / \mathrm{kg}$ [8], but the average energy content of rice husk is $15.84 \mathrm{MJ} / \mathrm{kg}$ [3]. This energy can serve as input fuel in a chain of processes for the co-generation of electricity and heat. The research analyzes the electricity and heat generation potential of rice husk via technologies whose commercial status has been established.

\section{METHODOLOGY}

Sets of thermo-chemical and thermo-dynamics equations were used to analyze the feasibility of electricity and heat generation by the alternative technologies utilizing rice husk as fuel. Only technologies that have been proven commercially for electricity and heat generation utilizing rice husk were considered in this study, hence thermo-chemical processes of gasification and combustion were considered. Pyrolysis is still undergoing development for commercial electricity production [4]. Bio-chemical processes for commercial electricity generation are still undergoing development [3]. The possible technology combinations to achieve a husk to electricity/heat energy conversion are summarized in Figure 1.

Figure 1 shows the four possible plant technology combinations, namely:

i. Plant A: steam turbine plant via heat from husk combustion 
ii. Plant B: steam turbine plant via heat from syngas combustion

iii. Plant C: gas turbine plant via syngas from gasification

iv. Plant D: IC engine plant via syngas from gasification.

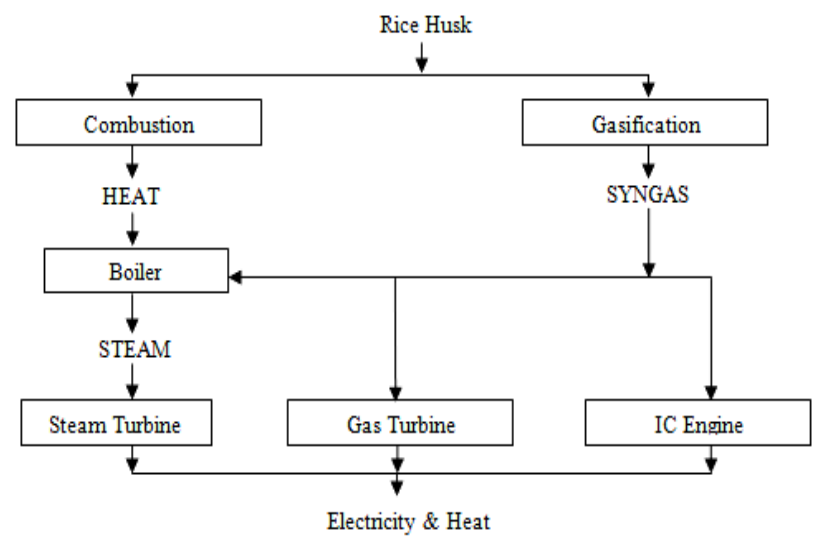

Figure 1: Husk to electricity/heat technology combinations

Figure 1 shows that, there are two major processes of converting biomass into energy that will in turn be used to generate electricity and heat. These are combustion and gasification. The direct combustion of rice husk biomass produces heat energy as its output which can be used to produce steam in boilers for the generation of heat and electricity when coupled to a steam turbine generator (Plant A). The gasification process on the other hand produces syngas as its output. The syngas can be burnt in a boiler to produce steam for heat and electricity generation via steam turbine generator (Plant B) or the syngas is used as fuel to produce electricity and heat via a gas turbine generator (Plant C), or the syngas is used as fuel in an IC engine to generate electricity and heat (Plant D). The analysis of the electricity and heat generation potential for the four plants is presented in the following subsections.

\section{THE POTENTIAL ANALYSIS OF THE ELECTRICITY AND HEAT GENERATION OF THE PLANT}

\subsection{Plant A}

Plant A is made up of two distinct major modules: the boiler module and the steam turbine generator module. The rice husk is burnt in the boiler to produce heat which increases the temperature of water to produce super heated steam at high pressure. The steam at the designed temperature, pressure and flow rate is let into the turbine chamber where it expands and does work by rotating the turbine which is coupled to a generator shaft for electricity production. The discharged steam from the turbine is condensed and pumped back to the boiler to complete the Rankine cycle on which the steam turbine generator operates [5]. The set of equations used to determine the electric power output and the thermal output of the plant is given by [5] as:

$$
\begin{aligned}
& H_{r}=Q \div h \\
& E_{i}=H_{r} \times v \\
& \dot{\mathrm{H}}=E_{i} \times \xi_{B} \\
& P_{e}=\xi_{S T e} \times \dot{\mathrm{H}} \times c_{f} \\
& P_{t}=\xi_{S T t} \times \dot{\mathrm{H}}
\end{aligned}
$$

Where: $H_{r}$ is the input husk rate to the system in $\mathrm{kg} / \mathrm{hrm}, \mathrm{Q}$ is the rice husk quantity in $\mathrm{kg}, \mathrm{h}$ is the number of hours of operation of the plant per year, $E_{i}$ is the total input energy to the system in $\mathrm{MJ} / \mathrm{hr}, \mathrm{v}$ is the $\mathrm{HHV}$ of the rice husk fuel in $\mathrm{MJ} / \mathrm{kg}, \dot{\mathrm{H}}$ is the input heat to steam turbine generator in $\mathrm{MJ} / \mathrm{hr}, \xi_{\mathrm{B}}$ is the efficiency of boiler, $\xi_{\mathrm{STe}}$ is the electric efficiency of the steam turbine in percentage (\%), $\xi_{\mathrm{STt}}$ is the thermal efficiency of the steam turbine in percentage (\%), $\mathrm{c}_{\mathrm{f}}$ is a conversion factor of 0.27777778 [6], $\mathrm{P}_{\mathrm{e}}$ is the electrical power output in $\mathrm{kW}$ and $\mathrm{P}_{\mathrm{t}}$ is the heat output in $\mathrm{MJ} / \mathrm{hr}$

\subsection{Plant B}

Plant $B$ requires that the rice husk is first converted to syngas via gasification. The syngas now serves as the fuel burnt in the boiler to produce steam for a steam turbine generator. Plant $B$, therefore, is made up of three distinct modules - gasifier module, boiler module and turbine generator module. Plant B operates just like plant $\mathrm{A}$ with the difference being the fuel being burnt in the boiler. The set of equations used to determine the electric power output and the thermal output of Plant A also served for Plant B except for Equation (2) which was replaced by Equation (6). The total input energy to Plant $\mathrm{B}$ is given by:

$$
E_{i}=H_{r} \times \xi_{G} \times v
$$

Where: $\xi_{G}$ is the efficiency of the gasifier in percentage (\%)

\subsection{Plant C}

Plant $\mathrm{C}$ is a combination of a gas turbine generator module and a gasifier module. The rice husk is gasified in the gasifier module to produce syngas which serves as fuel for the gas turbine module for electricity production. Equations (1), (6), (7) and (8) were used to determine the electric power output and the thermal output of Plant $\mathrm{C}$. The electric power output and heat output of Plant $\mathrm{C}$ are given by,

$$
\begin{aligned}
& P_{e}=\xi_{G T e} \times E_{i} \times c_{f} \\
& P_{t}=\xi_{G T t} \times E_{i}
\end{aligned}
$$

Where: $\xi_{\mathrm{GTe}}$ is the electrical efficiency of the gas turbine generator in percentage $(\%) ; \xi_{\mathrm{GTt}}$ is the thermal 
efficiency of the gas turbine generator in percentage $(\%)$

\subsection{Plant D}

Plant D comprises of a gasification module coupled to an IC engine. The rice husk undergoes gasification in the gasification module to produce syngas which in turn serves as input fuel for the IC engine. Equations (1), (6), (9) and (10) were used to determine the electric power output and the thermal output of Plant D. The electric power output and heat output of Plant D are given by,

$$
\begin{gathered}
P_{e}=\xi_{I C e} \times E_{i} \times c_{f} \\
P_{t}=\xi_{I C t} \times E_{i}
\end{gathered}
$$

Where: $\xi_{\text {ICe }}$ is the electrical efficiency of the IC engine in percentage (\%) and $\xi_{\text {ICt }}$ is the thermal efficiency of the IC engine in percentage (\%).

\section{DATA COLLECTION}

Relevant data was collected from a field study of an existing rice mill as well as scholarly literature which were used to evaluate the CHP potential of the four plants. The data collected and their sources are summarized in Table 1.

\begin{tabular}{|c|c|c|}
\hline Parameter & Value & Source \\
\hline HHV of rice husk & $\begin{array}{l}15.84 \\
\mathrm{MJ} / \mathrm{kg}\end{array}$ & {$[3]$} \\
\hline Electrical efficiency IC Engine & $33 \%$ & [7] \\
\hline CHP efficiency IC Engine & $78 \%$ & {$[7]$} \\
\hline $\begin{array}{l}\text { Electrical efficiency, gas } \\
\text { turbine generator }\end{array}$ & $36.5 \%$ & [7] \\
\hline $\begin{array}{l}\text { CHP efficiency, gas turbine } \\
\text { generator }\end{array}$ & $65 \%$ & [7] \\
\hline $\begin{array}{l}\text { Electrical Efficiency, steam } \\
\text { turbine generator }\end{array}$ & $7 \%$ & [7] \\
\hline $\begin{array}{l}\text { CHP efficiency, steam turbine } \\
\text { generator }\end{array}$ & $79.57 \%$ & [7] \\
\hline $\begin{array}{l}\text { Efficiency of fluidised boiler } \\
\text { (HHV) }\end{array}$ & $67 \%$ & [7] \\
\hline Efficiency of gasifier (HHV) & $71 \%$ & {$[7]$} \\
\hline $\begin{array}{l}\text { Rice husk available for CHP } \\
\text { generation per year }\end{array}$ & $\begin{array}{l}3507678 \\
\mathrm{~kg}\end{array}$ & $\begin{array}{l}\text { Field } \\
\text { study }\end{array}$ \\
\hline $\begin{array}{l}\text { Hours of Rice Mill operation } \\
\text { per year }\end{array}$ & $2688 \mathrm{hrs}$ & $\begin{array}{l}\text { Field } \\
\text { study }\end{array}$ \\
\hline
\end{tabular}

Table 1: Data collected and sources

\section{RESULTS AND DISCUSSION}

The results from the evaluation of the energy output of plants A, B, C and D are presented. This comprises the electric power output and the corresponding cogenerated heat output of the Plants for the same quantity of input husk. Figure 2 shows the total electric power output possible for each plant based on the quantity of husk available for electricity and heat generation at the mill, while Figure 3 shows the corresponding cogenerated heat output for the plants. Table 2 shows the annual electricity potential of the four plants and their corresponding quantity of husk required to produce $1 \mathrm{kWh}$ of electricity by the plants.

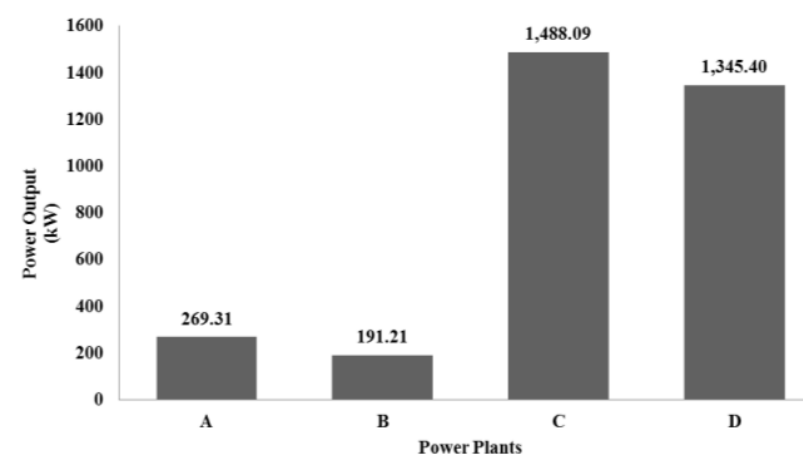

Figure 2: Power generation of the Plants based on husk availability

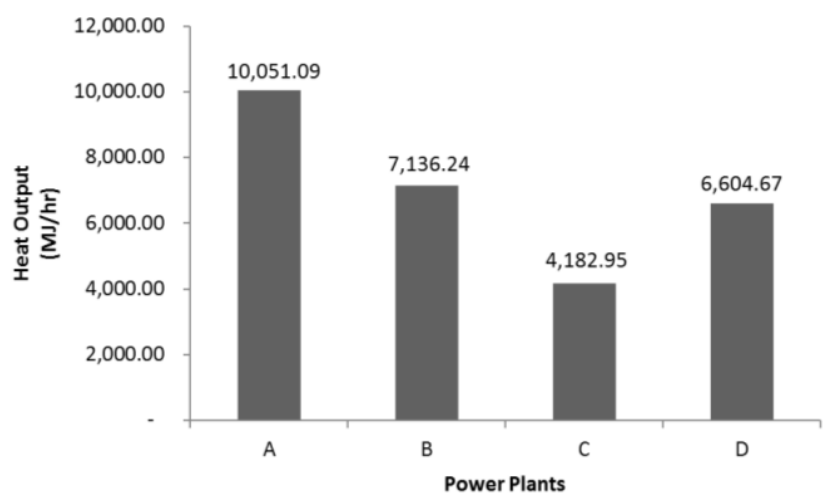

Figure 3: Heat output of the Plants based on husk availability

Table 2: Husk consumption rate and annual electrical energy production

\begin{tabular}{ccc}
\hline & $\mathrm{kWh}$ & $\mathrm{kg} / \mathrm{kWh}$ \\
\hline PLANT A & $723,905.28$ & 4.85 \\
PLANT B & $513,972.48$ & 6.82 \\
PLANT C & $3,999,985.92$ & 0.87 \\
PLANT D & $3,616,435.2$ & 0.97 \\
\hline
\end{tabular}

The power output of the plants A, B, C and D is presented in Figure 2. The graph shows that for the same quantity of input husk $(3,507,678 \mathrm{~kg})$, Plants A, B, $\mathrm{C}$ and D can generate $269.31 \mathrm{~kW}, 191.21 \mathrm{~kW}, 1,488.09$ $\mathrm{kW}$ and 1,345.40 kW of electric power respectively. This translates to an annual electricity generation potential of $723,905.28 \mathrm{kWh}, 513,972.48 \mathrm{kWh}$, 3,999,985.92 kWh and 3,616,435.2 kWh for Plant A, Plant $B$, Plant $C$ and Plant D respectively. Plant $C$ is the most efficient of the four plants requiring $0.87 \mathrm{~kg}$ of husk per $\mathrm{kWh}$ of electricity generation. Plant B is the 
least efficient plant requiring $6.82 \mathrm{~kg} / \mathrm{kWh}$. Plants $\mathrm{A}$ and $\mathrm{D}$ requires $4.85 \mathrm{~kg} / \mathrm{kWh}$ and $0.97 \mathrm{~kg} / \mathrm{kWh}$ respectively.

The potential for heat co-generation for the plants is shown in Figure 3. Plant A can generate 10,051.09 $\mathrm{MJ} / \mathrm{hr}$ of heat. Plants $\mathrm{B}, \mathrm{C}$ and D Can generate 7,136.24 $\mathrm{MJ} / \mathrm{hr}, 4,182.95 \mathrm{MJ} / \mathrm{hr}$ and $6,604.67 \mathrm{MJ} / \mathrm{hr}$ of heat respectively.

\section{CONCLUSION}

Through a simple analytical model, a method of determining the CHP potential of rice husk for off grid electricity and heat supply was developed.

The results obtained provide a relationship between the quantity of husk required to produce a unit of electricity and heat for the various conversion technologies considered.

The results shows that a gasifier-gas turbine CHP plant is the most efficient means of utilizing rice husk for CHP applications while a gasifier-boiler-steam turbine CHP plant is the least efficient.

\section{REFERENCES}

[1] Chungsangunsit, T., Gheewala, S. H., and Patumsawad, S., Environmental Profile of Power Generation from Rice Husk in Thailand. The Joint International Conference on "Sustainable Energy and Environment (SEE)" HuaHin, Thailand, Retrieved from https://www.researchgate.net/ 2004.

[2] Bergqvist, M. M., Wardh, S. K., Anjana, D. and Erik, O. A., "A Techno-Economic Assessment of Rice
Husk-based Power Generation in the Mekong River Delta of Vietnam", International Journal of Energy Research, 32, 1136 - 1150, 2008.

[3] Lim, J. S., Manan, Z. A., Alwi, S. R. W., and Hashim, H., "A Review on Utilisation of Biomass from Rice Industry as a Source of Renewable Energy". Renewable and Sustainable Energy Reviews. 16 (5), 3084 - 3094, 2012.

[4] Nguyen, T. T. Investigation of the Potential of Rice Husk based Power Plants and a Pre-feasibility Assessment of Possible Plants in the An Giang Province, Vietnam. Master of Science Thesis Chalmers University of Technology Göteborg, Sweden, pp. 7 - 9, 2014.

[5] Goldstein, L., Hedman, B., Knowles, D., Freedman, S. I., Woods, R. and Schweizer, T., Gas-Fired Distributed Energy Resource Technology Characterizations, 2003, Retrieved on September 10 from www.nrel.gov/docs/.../34783.pdf, 2015.

[6] Power Conversion Table, Retrieved on November 24 from https://www.aqua-calc.com/convert/ power/megajoule-per-hour-to-kilowatt, 2017.

[7] EPA, Biomass Combined Heat and Power Catalog of Technologies, 2007, Retrieved on September 03 from http://www.epa.gov/, 2015.

[8] Ezeike, G. O. I. "Determination of Calorific Values of some Nigerian Biomass Solid Materials", Nigerian Journal of Technology, Vol. 7, No. 1, pp. 21-33, 1983.

[9] Alhassan, M and Alhaji M. M. "Utilization of Rice Husk Ash for Improvement of Deficient Soils in Nigeria: A Review" Nigerian Journal of Technology, Vol. 36, No. 2, pp. 389 - 394, 2016. 